\title{
VERTICAL SOVEREIGNTY, HORIZONTAL CONSTITUTIONALISM, SUBTERRANEAN CAPITALISM: A CASE OF COMPETING RERTROACTIVITIES
}

\author{
JOHAN VAN DER WALT ${ }^{*}$
}

\begin{abstract}
This article engages with Andrew Arato's post-sovereign model of constitution-making. It does so with specific reference to Arato's claim that the South African constitutionmaking process constituted a 'perfection' of the post-sovereign model. It investigates this claim against the background of sceptical perspectives on the South African constitutionmaking process, especially those perspectives that view the South African transition and constitution-making process as more an outcome of a deal between the Apartheid Business Elite and the ANC leadership than of the round table negotiations that Arato takes as the heart of the post-sovereign process. The article ultimately defends Arato's claim with recourse to a Kelsenian contention which takes the impure origins of all law for granted, and recognises the need to fictionalise or presuppose pure foundations for the sake of entertaining the possibility of new law, and law as such.
\end{abstract}

\section{INTRODUCTION}

This article responds mainly to the model of post-sovereign constitution-making that Andrew Arato articulates in his contribution to this special issue of the South African Journal on Human Rights (SAJHR) on constitution-making, as well as in a number of other publications. ${ }^{1}$ However, it will also rely substantially on the other contributions to this special issue of the $S A J H R$ and will

Professor of Law, University of Glasgow; Honorary Professor of Law, University of the Witwatersrand; Professor Extra-Ordinarius, University of Pretoria. The thoughts articulated in this article emanated from discussions held during the Workshop on Constitution-Making held in Glasgow in May 2009. A special note of thanks is therefore due to everyone who participated in the workshop, but especially to the substantial contributions of Andrew Arato, Henk Botha, Halton Cheadle, Emilios Christodoulidis, Hans Lindahl, Martin Loughlin, Frank Michelman, Ulrich Preuss, Chris Thornhill, Scott Veitch, Francois Venter and Neil Walker. Andrew Arato, Frank Michelman and Ulrich Preuss have generously engaged in further discussions and correspondence after the workshop for which I also wish to thank them specifically. I also wish to thank Henk Botha, Danie Brandt, Emilios Christodoulidis, Dennis Davis, Wessel Le Roux, Hans Lindahl, George Pavlakos, André van der Walt, Karin van Marle and Scott Veitch for on-going scholarly cooperation from which the thoughts developed in this article also benefitted in innumerable ways. And specific note of thanks is also due to insightful discussions with my friend Peter John Massyn about socio-economic development in South Africa. All responsibility for errors and misunderstandings is of course strictly mine.

1 See in this volume A Arato 'Post-Sovereign Constitution-Making in Hungary: After Success, Partial Failure, and Now What?' (2010) 26 SAJHR 19. The other publications that I rely on are 'Constitution and Continuity in the East European Transitions I: Continuity and its Crisis' (1994) 1 Constellations 92; 'Constitution and Continuity in the East European Transitions II: The Hungarian Case' (1994) 1 Constellations 306; 'Forms of Constitution-Making and Theories 
take these contributions as already articulated points of departure that require no further questioning for now. I shall, instead, endeavour to build further on the thoughts developed in them.

I have little to add to Henk Botha's meticulous analyses of the competing assessments of the South African constitution-making process, the assessment of those who view the South African transition as an embodiment of the promise of an inclusive constitutionalism that constantly 'revisits its outside', and the assessment of those who view it as a failure that explains the political malaise in its wake. ${ }^{2}$ I bring to bear on Botha's analyses the central point of this article. The question whether the South African Constitution survives (and hopefully thrives) as a promise of an inclusive and truly post-apartheid constitutionalism or dies an early death lies in the hands of two competing retroactive discourses; the discourse that remains faithful to the Constitution's normative ideals and a discourse that abuses these ideals as a justifying facade for self-advancement, new exclusions and new forms of apartheid.

There is also very little that I can add to Francois Venter's careful documentation of the rather less than liberal constitutionalist records of the two major political participants in South Africa's constitutional negotiations, the African National Congress (ANC) and the National Party (NP). ${ }^{3}$ I shall rely on Venter's assessment in this regard and emphasise his key point regarding the need for the all political role-players in South Africa to 'claim ... for [themselves]' the liberal constitutional product of the negotiations, unintended as it may have been, 'as their own'. My aim will be to stress that a certain 'claiming for itself' of something that is 'not entirely one's own', is an essential feature, not only of Arato's concept of post-sovereign constitution-making, but also of liberal constitutionalism.

I also take on board Dennis Davis' understanding of judicial interpretation and application of the Constitution as a form of on-going constitution-making as a central premise of my argument. I have already highlighted the importance and exigencies of Davis' concept of transformative constitutionalism in the Editor's Introduction to this volume with reference to André van der Walt's invocation of a 'renunciation of everything the apartheid legal order represented'. I have shown there that the transformative constitutionalism embodied in the South African Constitution demands in fact an irreducible future imperfect renunciation of all present and future forms of apartheid, not only that of the past. What follows in this article is an articulation of the essential 'plurality of the political' and 'plurality of constitutionalism' that the renunciation of apartheid must take as its regulative ideal.

of Democracy' (1996) 17 Cardozo LR 191; 'Post-Sovereign Constitution-Making and its Pathology in Iraq' (2006) 51 New York Law School LR 535; 'Constitutional Learning' (2005) 106 Theoria 1; 'Redeeming the Still Redeemable and Post-Sovereign Constitution-Making' (2009) 22 International Journal of Politics Culture and Society 427; Civil Society, Constitution, and Legitimacy (2000).

2 H Botha 'Instituting Public Freedom or Extinguishing Constituent Power? Reflections on South Africa's Constitution-Making Experiment' (2010) 26 SAJHR 66.

3 F Venter 'Liberal Democracy: The Unintended Consequence - South African Constitution-Writing Propelled by the Winds of Globalisation' (2010) 26 SAJHR 45. 
The endorsement of Venter's assessment of the less than liberal constitutional democratic records of the ANC and NP may raise eyebrows among, not only specifically pro-ANC, but also generally anti-apartheid, liberal, left-leaning and progressive observers of the South African transition. The general or broad political alignment at issue here does not appreciate equations between the ANC and NP that blur the fundamental difference between their respective moral and normative standings. However, as little as one can doubt that the ANC went into the constitutional negotiations on the basis of a political morality that was vastly superior to that of the NP, can there be doubt about the fact that they did not, surely not initially, consider a western-style liberal constitutionalism as a necessary vehicle for realising their superior moral and political vision for the future of South Africa. ${ }^{4}$ And the fact that the NP came round to seeing the light of liberal constitutional democracy some time before the ANC did, most likely attested less to moral awakening than it did to a self-interested compromise with the inevitable. ${ }^{5}$

Against this background of obvious respective moral superiority and inferiority, a vertical form of constitution-making by a sovereign constituent power calling the shots from above, would not have been surprising. The ANC did not do this and the question that historians will or should be asking for many years to come still, is 'why?'. Instead, the ANC went into a horizontal constitution-making process in terms of which all parties negotiated on an equal footing and generally low-levels of brinkmanship. The Pan African Congress would at one stage (March 1993) storm out of the negotiations, accusing the ANC of selling out. But only twice did the ANC force significant showdowns with the NP. In the one case they pulled out of the negotiations after the Boipatong massacre of 17 June 1992, accusing the NP government of fuelling township violence between ANC and Inkatha supporters by means of 'third force' interventions. The only other incidence of real resistance and brinkmanship led to the breakdown of the Convention for a Democratic South Africa (CODESA) I. At issue was the intractable disagreement about the majority that would be required to accept the interim Constitution (eventually the 1993 Constitution). The ANC insisted on two-thirds, the NP on 75 per cent. When no consensus seemed to be possible, the ANC resorted to a mass action campaign to break the deadlock. ${ }^{6}$ But the resistance of the ANC pales in comparison with the Cuban-backed resistance of the South West Africa People's Organisation (SWAPO) during the constitutional negotiations for the future Namibia. Chester Crocker, the United States Assistant Secretary for Africa, would observe the following regarding the role of the Cubans during the Namibian negotiations: end of apartheid and early years of transition in J van der Walt 'The Human Rights Debate in South Africa: A Historical and Historicist Perspective' in De Lange et al (eds) Human Rights and Property: A Bill of Rights in a Constitution for a New South Africa 19(3) Recht en Kritiek 14.

5 See Van der Walt ibid 18.

6 For discussions of these developments see F Cachalia 'A Progress Report on Codesa' (1992) 8 SAJHR 254; Van der Walt (note 4 above) 24-5. 
Reading the Cubans is yet another art form. They are prepared for both war and peace. We witness considerable tactical finesse and genuinely creative moves at the table. This occurs against the backdrop of Castro's grandiose bluster of power and his army's unprecedented projection on the ground. ${ }^{7}$

Was it mere concern of military intelligence and the insight from both sides that a military battle was not to be won in South Africa that head-locked the $\mathrm{NP}$ and the ANC into a negotiation process in which they took one another, surely not as moral equals, but at least as political equals? Was this why a threat to return to arms was seemingly so out of the question on the side of the ANC? One should hope so, for perceptions of a stalemate balance of power and the need to avoid further bloodshed and suffering are sound reasons for turning to a horizontal (equal footing) negotiation process, however much moral high and low grounds may hold the negotiators apart. ${ }^{8}$ But one nagging suspicion regarding the relatively smooth character of the South African negotiation process does not seem to go away and frequently surfaces in academic and journalistic circles in South Africa. The suspicion is that far from entering the negotiation process horizontally, that is, graciously on an equal footing that the NP surely could not demand, the ANC entered the negotiations supinely committed to a deal they had already made with the South African business elite. Were this to be the most accurate assessment of what really happened during the South African transition, it would go a long way towards explaining one of the key developments that threatens constitutional democracy in South Africa today, namely, the political culture of political patronage and rent-collecting political elites that frustrate real economic growth and thus make a mockery of the 'progressive realisation' of key constitutional rights and the general imperative of transformative justice demanded by the South African Constitution (section IV returns to this point in more detail). This culture may even continue to demand or concede to the demands of a perfunctory constitutional democracy. It often does so for purposes of the international presentability required to maintain sufficient levels of foreign investment on which it becomes more and more dependent. ${ }^{9}$ Dependency of rent-collecting patronage on foreign investment tends to increase steadily, given the way such patronage undermines or contributes too little to the development of genuine local industrial and economic capacity.

Heaven forbid that increasing dependence on foreign investment and attendant concerns with presentability become the last saving grace of 'constitutionalism' in South Africa. For such a development will leave little to celebrate among those who actually happened to believe in the aspirational

7 In a cable to the US Secretary of State George Shultz on 25 August 1988. See 'Cuito Cuanavale Revisited' <http://emba.cubaminrex.cu/Default.aspx?tabid=15471>; and R Kasrils 'Turning Point at Cuito Cuanavale' Sunday Independent (23 March 2008).

8 Arato also understands this balance of power situation as the most conducive for the post-sovereign constitution-making he has in mind. See Arato 'Post-Sovereign Constitution-Making and its Pathology in Iraq' (note 1 above) 538, 543.

9 See HK Prempeh 'Africa's “Constitutional Revival”: False Start or New Dawn?' (2007) 5 Int J of Constitutional Law 3-4; and also my references to Prempeh in the Editor's Introduction to this volume. 
ideals of constitutional democracy reflected in s 1 of the South African Constitution. And there will of course also be little to celebrate among those who remain excluded from the small circle of benefits generated by this quasifeudal 'capitalist' economy. Suggestions of causal connections between the relatively smooth progress of the South African constitution-making process, on the one hand, and subsequent political malaise, on the other, would then become almost too obvious to allow for plausible refutation. Surely, many will then come to insist that there must be some degree of continuity between subsequent integrity and initial sincerity to render the latter plausible. This understandable line of thought is bound to invite future historical research bent on proving that the culture of rent-collecting patronage that is currently developing in South Africa was all along contemplated by the ANC in their deal with business. The more such research gains currency, the more difficult it would become to sustain faith in the moral high ground of the ANC leadership and the selfless gift they offered to South Africa by not insisting on this moral high ground in the course of the constitutional negotiations. One would then also have to revisit Venter's poignant assessment regarding signs of failure on the part of the ANC subsequently to embrace and claim for itself the ideals of constitutional democracy. At issue in Venter's invocation of 'unintended consequences' are of course only consequences that the ANC did not contemplate when the constitutional negotiations began. Should the view that the ANC leadership was only concerned with the benefits that would come with power increasingly gain ascendancy in historical narratives about South Africa's constitution-making process, it would leave us to consider an entirely different sense of unintended consequences, namely, consequences that were never sincerely intended, neither in the beginning nor towards the end, but simply co-opted all along for purposes of pursuing ulterior motives.

I return to all these suspicions and concerns towards the end of this article. Suffice it to exclaim again for now: Heaven forbid that this is the truth in the offing in South Africa today. For not only would this truth make a cynical mockery of the bloodshed and untold suffering and the avoidance of more of it that in the minds of many still constitute the living heart and real sacrificial substance of the South African transition and constitutional peace. It would also render all the earnest and critical scholarly engagements with the normative ideals of the South African Constitution a rather pointless affair and a naive one at that. It would render pointless and naive, if not indeed unwontedly complicit, the aspirational work that hundreds of sincere and serious legal and political scholars have been doing in this and other proud law journals in South Africa. And Andrew Arato, one of the finest political theorists in the world today, would have paid a tribute to South Africa that it never deserved. Instead of perfecting the fine model of constitution-making that he describes and promotes in his work, South Africa would have worn this model like a mask to hide a dishonourable reality. The apparent 'perfection' would of course also be no wonder then, for one would naturally resort to perfect counterfeiting when the reality for sale is intentionally bankrupt. Again, heaven forbid that this is how we will one day look back at what we are doing today. 
This article shall nevertheless assume or presuppose that our endeavours here and our general engagement with the liberal norms of constitutional democracy in South Africa remain meaningful and important. Perhaps we are little more than torchbearers. We carry the fire Cormac McCarthy style..$^{10}$ But torch-bearing may always have been the heart of constitutional democracy. We have it from Hans Kelsen that the rule of law never really exists; it exists only by virtue of an assumption or a presupposition that we make every time we begin to talk about law. ${ }^{11}$ And this assumption or presupposition, I hope to show, is also crucial for the notion of horizontal constitution-making and horizontal constitutionalism that I wish to develop in response to Arato's model of post-sovereign constitution-making.

At issue in this article is ultimately an engagement with two competing narratives of retroactivity. The first narrative concerns a destructive retroactivity in terms of which the current political malaise in South Africa increasingly functions as proof for the fact that the South African constitution-making process was a sham; that the South African transition was just another case of a self-interested power struggle, one ultimately won, at that, by politically dubious business deals behind the scenes. The second narrative concerns the positive retroactivity that faithfully refuses to accept that a leadership that had sacrificed so much for their ideals would have come so far only to sell out for the sake of petty private interests. Which of these two narratives win the day will determine whether South Africans can continue to meet their future with hope and aspiration or are doomed to incurable cynicism. This article wishes to endorse and strengthen the latter narrative unequivocally, not only for purposes of sustaining the hope that it affords, but also because cynicism is such a facile and uninteresting theoretical position to take. Naive idealism is, however, not less facile than cynicism and surely not more convincing. A convincing response to cynicism demands an honest engagement with its claims. It is for this reason that the first narrative, the narrative of destructive retro-activity, enjoys the extensive attention in this article that it does.

The article proceeds in five steps. Section II relates Arato's post-sovereign constitution-making to the legacies of two other political and legal theorists, namely Hans Kelsen and Hannah Arendt. It does so to show how post-sovereign constitution-making addresses the essential plurality deficit that characterises all apartheids, not just the racist version of apartheid that resulted from the history of white supremacist colonialism and nationalism in South Africa. Section III links the quest for plurality to an economy of the gift, giving and forgiving. It argues that this economy is central to Arato's model of post-sovereign constitution-making. As such the model displaces the economy of sacrifice that characterises and informs all conceptions of sovereign constitution-making. Section IV finally returns to the South African transition and constitution-making process and poses the question whether a surreptitious economy of sacrifice has not in fact subsequently displaced the 
economy of the gift with which the negotiations commenced. The focus in section IV is on the frustration of socio-economic development in South Africa by current Black Economic Empowerment (BEE) programmes. Section V relates the questioning in section IV to the amnesty procedures conducted by the Truth and Reconciliation Commission (TRC) and briefly asks the question whether, instead of promoting the gift of forgiveness, it simply imposed another sacrifice on those oppressed by apartheid. Section VI ends the article with a concluding observation.

\section{Post-Sovereign Constitution-Making and Post-Apartheid Plurality}

What did the apartheid legal order represent apart from just racism? One way of coming to grips with this question is to look again at a key phrase that Hendrik Verwoerd used to describe what the NP had in mind for South Africa: 'apartness without partnership.'2 The Verwoerds of this world envisaged a South Africa in which the different peoples that lived here would share nothing. They would have nothing in common. As one of their ideological slogans put the matter, they would 'develop separately'. Another slogan would invoke the notion of 'plural relations' (to rename, in fact, the Department of Bantu Affairs as the Department of Plural Relations) between the peoples of South Africa, or rather, between the white population and the other populations. ${ }^{13}$

Those who lived through these toxic times will recall how some whites deridingly referred to black people as 'plurals'. And yet, 'plurality' was exactly and evidently what the NP's apartheid was not about. The NP's apartheid was essentially an exclusive concern with 'own affairs' at the complete expense of the affairs of others, and at the complete expense of any real concern with 'plural relations'. ${ }^{14}$ South Africa was surely 'no country for black men' at the time. But there is more to this than just this. The apartheid of the years of NP government was for a long time sufficiently totalitarian and single minded to render any critical political engagement with it practically pointless. Should anyone have doubts about this, a brief recollection of the Sharpeville massacre in 1961 should dispel it quickly enough. It was not for nothing that the ANC resorted to armed resistance in 1962. They were up against a government who would not consider them as a legitimate political partner and participant. No plurality was recognised here where it really mattered. This is why there can strictly speaking never be such a thing as an apartheid politics. Politics, Hannah Arendt teaches us, is conditioned by plurality:

$[\mathrm{P}]$ lurality is ... the conditio sine qua non [and] conditio per quam of all political life. ${ }^{15}$

12 For a fuller discussion of this point, see Van der Walt Law and Sacrifice (2005) 123-4.

13 See K Tomaselli 'Myth, Media and Apartheid' 34(1) 1987 Media Development 18-20<http://ccms. ukzn.ac.za/index.php?option $=$ com_content\&task=view\&id=625\&Itemid=72>.

14 This became abundantly clear from the fate of the Tomlinson Report of 1956. For a brief discussion of the report, see again Van der Walt (note 12) 123-4.

15 H Arendt The Human Condition (1989) 7. 
Politics, she would stress further, is a reflection of the plural condition of human existence. ${ }^{16}$ From this perspective, NP South Africa was not only no country for black men. It was no country for men (let alone men and women). It was no country for the differing opinions that condition the plurality of human existence. The accusation that you are 'against us if you are not with us' was levelled at anyone who at least meekly resisted the system, whites included. And let one not forget the annihilation also of whites who resisted more than meekly. Let one not forget the David Websters and Neil Aggetts of this world. If the crime of the National Socialism was a crime against humanity for reasons of having offended the very plurality of the human condition by seeking to destroy a race, as Arendt would argue, ${ }^{17} \mathrm{NP}$ apartheid surely was another. ${ }^{18}$ Literally seeking to destroy a race is surely not the only way that the plurality of humanity is offended. It is offended, of course on a lesser scale, every time someone is forcefully and/or fatally prevented from expressing and pursuing a dissenting opinion. ${ }^{19}$

If politics ultimately concerns the plurality that conditions the human, as Hannah Arendt insists, South Africa was surely no country for politics. However one might describe the social engineering that went by the name of apartheid in South Africa, it was not in the least about politics in the Arendtian sense of the word. This may well be what André van der Walt had in mind when he recently linked 'the renunciation of everything the apartheid legal order represented' repeatedly to a concern with 'giving politics a chance'. ${ }^{20}$

The transformative justice demanded by the Constitution concerns a constitutional call for a politics that is not a matter of unilateral social engineering, but a real experience of and experiment with plurality, a real experience with the multiplicity of voices and faces that makes a polity a polity and a city a city. Concrete concerns of constitutional review aimed at transformative justice would today have to target the ways in which South African politics have again degenerated into unilateral schemes that insiders implement at

16 ' $[\mathrm{M}] \mathrm{en}$, not Man, live on the earth and inhabit the world'. Ibid.

17 Arendt Eichmann in Jerusalem (1994) 268-9.

18 Hence also recognised as such by art 7 of the Rome Statute of the International Court $<$ http:// untreaty.un.org/cod/icc/statute/romefra.htm>.

19 Arendt would not have agreed with this, but there is a conceptual instability in her argument that merits some questioning and revision. She herself mentions that 'expulsions of Nationals' can already be seen to constitute an offence against humanity, but only if humanity is defined as the 'comity of nations' that was obliged to receive the unwanted nationals. Genocide is different, she contends, because it is a crime against the 'diversity' of the 'human status', not just against 'fellow nations' (note 17 above) 268-9. This is not a sound argument, for it invites the facile but forceful retort that the National Socialists only wanted to terminate the existence of 'remaining' Jews in Germany, not in the rest of the world. There is also a biologist or naturalistic element in her understanding of humanity's 'status of diversity' here that is not in keeping with her own emphatic link between plurality and the freedom to express different views in The Human Condition. Once a general crime against the diversity of the human is contemplated, it must surely include all crimes that offend this diversity. That there can be the more and less serious crimes against the diversity of the human, ranging from genocide, on the one hand, to, for instance, mere suppression of political freedom and freedom of speech, on the other, goes without saying.

20 See A van der Walt 'Normative Pluralism and Anarchy: Reflections on the 2007 Term' (2008) 1 Constitutional Court Review 81; 82; 87; 90; 98; 99; 100; 105; 127. 
the expense of outsiders. On the micro level (petit apartheid) one sees this happening in the pervasive ways urban development, property schemes and architecture again separate people so as to privilege and secure the wellheeled few. ${ }^{21}$ On the macro level (grand apartheid) one sees this in the way much-needed programmes and policies required to end economic white-black apartheid (white wealth-black poverty) by bringing about black economic empowerment, degenerate into schemes that privilege a small number of well-connected insiders at the expense of the masses that continue to live in squalor. ${ }^{22}$ It is not that nothing is being done to improve the living conditions of the poor. Those who wish to say this probably also have some unfounded, pernicious and dubious axe to grind. The problem is only that social welfare concerns increasingly seem to degenerate into poverty management schemes that keep the boundaries between rich and poor and between the empowered and disempowered stable if not impenetrable. In this respect, the poverty management schemes that are steered against the background of conspicuously exclusive BEE package deals in the echelons of high finance increasingly resemble the social engineering schemes of the NP in the heyday of white-black apartheid.

This new apartheid between insiders and outsiders is quite in keeping with the claim of some that this was what the South African constitution-making process was all about since the beginning. Indeed, from this perspective the whole process of constitutional negotiations would appear to have been little more than a facade that hid a done deal between a couple of insiders. Should there be any substance to this view, the current malaise in South African politics would surely not just be a subsequent development, but something that can be traced right back to the constitution-making process itself. I wish to show that one need not and should not get stuck in this bleak view. We have law, we learn from Kelsen, only to the extent that we faithfully presuppose the existence of law. But this also means that we still have law as long as enough of us are willing and committed to do so. The same applies to South African law, South African constitutionalism, and by implication, the South African constitution-making process. Arato too, we saw in the Editor's Introduction above, articulates in true Kelsenian style the insight that the legacies of constitution-making processes ultimately depend on the faithful maintenance of fictions. The faith of the sons and the daughters may therefore yet redeem whatever disingenuousness the fathers may have committed. So let us take a closer look at the model or fiction of constitution-making to which Arato invites us to bear witness so as to give it a chance.

21 For a further discussion of this new urban apartheid, see $\mathrm{J}$ van der Walt 'Johannesburg, A Tale of Two Cases' in A Philippopoulos-Mihalopoulos (ed) Law and the City (2007) 221; A van der Walt 'Enclosed Property and Public Streets' (2006) 21 SAPL 3; W Le Roux 'Planning Law, Crime Control and the Spatial Dynamics of Post-Apartheid Street Democracy’ (2006) 21 SAPL 25.

22 Let us think again of Irene Grootboom's and Danderine Bailey's stories. See J van der Walt 'Agaat's Law. Reflections on the Relationship between Law and Literature with Reference to Marlene Van Niekerk's novel Agaat' (2009) SALJ 695. 


\section{Arendt, Arato And the Plurality of the Political}

That Arato's thinking on constitution-making is deeply influenced by Arendt is especially evident in his endorsement of her dualistic understanding of the constitution-making process in terms of which the process 'always' remains 'under law' or subject to the rule of law and in this sense constitutes no complete revolutionary rupture with the past, despite the fundamentally new constitutional order that the process creates and inaugurates. Arato's Arendtian constitutionalism thus endorses a dualism of constitutional continuity and legislative change. ${ }^{23}$ This dualism clearly falls by the wayside in the tradition or discourse of constitution-making in post-colonial Africa, as I showed in the Editor's Introduction to this volume with reference to Kwame Nkrumah, Julius Nyerere and King Sobhuza II. And as Francois Venter's contribution to this volume shows, this constitutional dualism is also clearly under pressure in South Africa today.

However, I wish to stress in this section another fundamental Arendtian element in Arato's model of constitution-making, namely Arendt's emphasis on the plurality of the political that I introduced in the previous section. That this emphasis on plurality informs Arato's model from beginning to end is clear throughout his writings. ${ }^{24}$ Consider in this regard just this striking formulation as an example:

If 'the people' can be said to be present in th[is] new type of [post-sovereign] constituent process this is so in a plural, complex, and always limited way that has neither the possibility of the absolute no of the referendum, nor the unlimited constituent power incorporated in an assembly. ${ }^{25}$

23 This dualism, Arato points out, is also endorsed in significant ways by Bruce Ackerman, especially by Ackerman's preference for a constitutional convention (that operates separate from ordinary legislative powers such as Parliament or Congress) instead of a Constitutional Assembly (that unites constitution-making and legislative powers) or Parliament as the proper forum for constitutionmaking, given that the latter two fora tend to blur the line between constitution-making and ordinary legislation), the ultimate threat of which is a permanent constitutional revolution that never succeeds in establishing a constitutional order. However, the duality is also fudged or undermined to some extent, argues Arato, because of Ackerman's insistence, echoing Schmitt here, that the constitution-making process concerns an illegal revolutionary act. This insistence fudges the deep duality between the timeless continuity of constitutional principles, on the one hand, and legislation, on the other, given the way it reduces the former to a 'legislative' product that is in many ways indistinct from the latter. The difference between Arendt and Ackerman, in short is this: Ackerman, like Arendt, endorses 'a dualistic outcome' that stresses the difference between constitution law and legislation, but unlike Arendt, believes this outcome can result from a 'monistic revolutionary beginning' during which constitutional law is as made (illegal at that for reasons of breaking with all existing legality) as legislation. See Arato 'Forms of Constitution-Making' (note 1 above) 205-19, especially 211-3, and Civil Society, Constitution, and Legitimacy (note 1 above) 239-47.

24 Arato in fact highlights the 'plurality of democracies' as one of the principles of the constitutional thinking that informs the post-sovereign model. See 'Forms of Constitution-Making' (note 1 above) 226-7.

25 Arato 'Post-Sovereign Constitution-Making and its Pathology in Iraq' (note 1 above) 540. 
The counter pole of this concern with the plurality of the political is surely Schmitt's understanding of the political in terms of the unity of sovereignty. ${ }^{26}$ The Schmittian notion of the unity of sovereignty assumes the unity of the people in a very fundamental sense, so much so that it takes a people to constitute a first person plural, a 'we' and an 'us' that can invoke an 'ours'. This Schmittian assumption is clearly evident in post-colonial African constitutional discourses as African invocations of constitutions that are 'ours' and even 'entirely ours' make clear. Consider the following statements by Julius Nyerere and Sobhuza II:

[T] ]he Independence Constitution of Tanganyika was neither particularly suited to the needs of development nor was it entirely ours. ${ }^{27}$

The emphasis on 'entirely ours' is added here. It is this expression that I wish to address. Compare a similar statement of King Sobhuza II of Swaziland when he abrogated the Constitution of 1973:

$[T]$ he [independence] constitution has failed to provide the machinery for good government and for the maintenance of law and order, [and] .... I and my people heartily ... desire to march forward progressively under our own constitution guaranteeing peace, order and good government. ${ }^{28}$

This time the emphasis has already been added by HWO Okoth-Ogendo from whom I took over the quote. The focus is again on the notion of our own constitution. There is a considerable and perhaps growing sentiment among some South Africans that the Constitutions of 1993 and 1996 are not 'our own' or not 'entirely ours'. They are expressions of the liberal and individualistic values of western societies. This sentiment registers frequently in the South African media and has recently come to the fore with full force in an opinion piece that the Judge President of the Pretoria High Court published in a Sunday newspaper. Judge Ngoepe expressly took issue with the liberal values, if not of the Constitution, at least of the jurisprudence of the Constitutional Court. And he surely expressed the need to replace these western values with local ones:

Should we go to Washington, Canada or London and ignore as points of reference the values as perceived by say, tribesmen and women in the rural areas? $?^{29}$

26 C Schmitt Der Begriff des Politischen (1996) 39: 'Sie ist deshalb immer die maßgebende menschliche Gruppierung, die politische Einheit infolge dessen immer, wenn sie überhaupt vorhanden ist, die maßgebende Einheit und "souverän" in dem Sinne, daß die Entscheidung über den maßgebenden Fall, auch wenn das der Ausnahmefall ist, begriffsnotwendig immer bei ihr stehen muß. Das Wort "Souveränität" hat hier einen guten Sinn, ebenso wie das Wort "Einheit".

27 J Nyerere Freedom and Development/Uhuru na Maendeleo (1973) 174.

28 As quoted by Okoth-Ogendo 'Constitutions without Constitutionalism: Reflections on an African Paradox' in D Greenberg et al Constitutionalism and Democracy. Transitions in the Contemporary World (1993) 65, 68.

29 See B Ngoepe 'Choosing New Custodians of Our Constitution' Times Live (30 August 2009) $<$ http://www.timeslive.co.za/sundaytimes/article34943.ece>. For a poignant articulation of the issues in play, see for example Serjeant at the Bar 'Concourt's Heavy Burden' Mail\& Guardian (10 October 2009) <http://www.mg.co.za/article/2009-10-10-concourts-heavy-burden>. For a liberal response to Ngoepe J's 'conservative' views, see E McKaiser 'The Darker Side of Conservatism' Mail\&Guardian (5 September 2009) <http://www.mg.co.za/article/2009-09-05-the-darker-side-of- 
The sentiment expressed here also finds forceful expression in current academic writing in South Africa, notably that of Mogobe Ramose. ${ }^{30}$ And it is worthwhile also recollecting in this regard the sublime expression given to the existential need experienced by Black Consciousness writers to replace western with African values. Consider in this regard the words of Steve Biko:

\footnotetext{
In rejecting Western values, therefore, we are rejecting those things that are not only foreign to us but that seek to destroy the most cherished of our beliefs - that the corner-stone of society is man himself - not just his welfare, not his material wellbeing but just man himself with all his ramifications. We reject the power-based society of the Westerner that seems to be ever concerned with perfecting their technological know-how while losing out on their spiritual dimension. We believe that in the long run the special contribution to the world by Africa will be in this field of human relationship. The great powers of the world may have done wonders in giving the world an industrial and military look, but the great gift still has to come from Africa - giving the world a more human face. ${ }^{31}$
}

Crucial themes abound in this remarkable passage and I shall revisit it below to engage with the notion of the gift and giving that it raises. Suffice it to state for now that it crowns the expression of the need for a constitution that is 'entirely ours' and 'our own' expressed by Nyerere and King Sobhuza II with a deep aspirational articulation of the sentiments that currently appear to inform pervasive discontent with the South African Constitution. Faith in the Constitution and the constitution-making process that brought it into being and faith in Arato's model of constitution-making cannot and must not blind one to the fact that these sentiments are real and deep and legitimate and entitled to sincere respect. This respect, however, can also not prevent one from asking, or absolve one from the task of asking, how the indigenous aspirations voiced here can seriously hope to become the exclusive foundation for co-existence in social contexts that are 'irremediably' heterogeneous, fragmented, multi-cultural, mixed and mixed-up in more ways than we can fathom, without risking a new apartheid; without risking again a purity driven apartness without partnership. It is with this question in mind that I now wish to return to the question of the irreducible plurality of the political and the tension between this understanding of the political and another one, one that stresses the irreducible unity of the political. For this tension is clearly what is at stake between the two opposing traditions of constitution-making that

conservatism>. See also SS Alcock's interview with former Constitutional Judge Johann Kriegler 'Kriegler Saddles up for Rough Ride' in the Mail\&Guardian (11 September 2009) <http://www. mg.co.za/article/2009-09-11-kriegler-saddles-up-for-rough-ride>. Kriegler notably remarked during the interview that ' $\mathrm{t}$ ] he Bill of Rights is a Western thing', clearly suggesting there is little judges can do about having to apply liberal western values. For a further discussion of these developments and many more references to scholarly and journalistic attention to them, see F Michelman 'Legitimation by Constitution (And The News From South Africa)' (2010) 44 Valparaiso Uni LJ 1015.

30 M Ramose 'In Memoriam. Sovereignty and the "New" South Africa' (2007) 16 Griffith LR (2007) 310; 'The King as Memory and Symbol of African Customary Law' in MO Hinz (ed) The Shade of New Leaves. Governance in Traditional Authority (2006) 351; 'An African Perspective on Justice and Race'<http://them.polylog.org/3/frm-en.htm>.

31 S Biko I Write What I Like (A selection of Biko's writings edited by Aelred Stubbs) (1979) 46-7. 
have emerged clearly in constitution-making processes in the wake of World War II.

The one tradition is the one on which Arato's post-sovereign constitutionmaking model is based, the tradition of round table constitutional negotiation processes between liberators and former oppressors or former enemies in the course of which the fundamental concerns of all parties to the process are accommodated in the resulting constitution, irrespective of questions regarding the moral standings of the various participants. The other tradition is the one in which a liberation movement or military victor unilaterally moves to lay down the foundations for a new polity on the basis of convictions of justice and national concerns that are 'entirely our own'. This tradition clearly emerges from the post-colonial liberation struggles in Africa, starting from Nkrumah's Ghana and including further, to name just those revisited above, Nyerere's Tanzania and King Sobhuza II's Swaziland. The constitutionmaking process in South Africa may have been an expression of the former tradition, but much of the political tension surrounding the outcome of this process evidently relates to the pervasive perception that the latter tradition is the more appropriate or only appropriate one in the minds of many South Africans.

Now, constitutions that result from either of these two traditions may eventually pass as 'our constitution', once the constitution-making processes are over, not only those in which this first person plural genitive pronoun is emphasised as the essential force that drives or informs the whole process from beginning to end. But it is surely evident that the two 'ours' that would be at issue here, would differ fundamentally. In the one case, in the postsovereign tradition, the 'our' would turn on a subsequent appropriation of something that was not 'ours' or surely not 'entirely ours' from the beginning. And in this case, the initial deficit of first person plural possession would, given the fundamental compromises that can be expected always to have entered the final outcome of the process, remain an essential feature of this constitution. In this case, the constitution would have to be appropriated and re-appropriated repeatedly and continuously to overcome the first person plural possession deficit, until such time as something that John Rawls might have called a collective modus vivendi actually turns into a real overlapping consensus. It is a good question whether this transformation of a collective modus vivendi into real consensus can ever be conclusive or stable. ${ }^{32}$ Suffice it to point out for now that one again touches here upon the profound significance of Francois Venter's point regarding the need for all South Africans to claim for ourselves/for themselves constitutional ideals that were not entirely or not even significantly ours/theirs. In no country where a constitution serves to facilitate the functional coexistence of people and peoples with deeply different cultural, religious and general political backgrounds, will any of those people or peoples ever be able to claim that the constitution is entirely theirs 
or entirely ours. Rawls' distinction between public reason and comprehensive worldviews relies heavily on exactly this insight. ${ }^{33}$

In the other case, in the tradition of unilateral sovereign constitution-making, the constitution that comes out of the constitution-making process will surely be appropriated and promoted as 'our own' or 'entirely ours', but there can be no doubt that this 'ours' will be significantly imposed on others whenever this sovereign and unilateral appropriation and promotion of the constitution is accompanied by significant degrees of social, religious and general political plurality and difference. Carl Schmitt was abundantly clear about the fact that the sovereign constitution-making that he had in mind turned on a substantive sameness (susbstantielle Gleichheit) between the ruler and the ruled. Only under circumstances of such existential sameness could a sovereign constitution be claimed not to inhibit or restrain the liberty of anyone subject to that constitution. ${ }^{34}$ The inevitable element of constitutional imposition under circumstances where one cannot assume such existential sameness between rulers and ruled explains and informs Arato's point regarding the tendency of such sovereign constitution-making processes to degenerate all too frequently and usually very soon at that, into the same kind of dictatorship that they sought to overcome. ${ }^{35}$ Should one wish to avoid such dictatorial impositions of constitutions by some on others, one needs to conceptualise democratic constitutionalism as fundamentally a concern with accepting and living with irreducible differences between the people that are united by a system of law. I return to this point with reference to John Rawls and Frank Michelman below. But it is worthwhile to recall also Kelsen's insight into the link between constitutionalism and the irreducible differences that prevail within modern political communities and the compromises that these differences exact. ${ }^{36}$

34 C Schmitt Verfassungslehre (2003) 228-38, especially 234-5. For insightful discussions of Schmitt's position in this regard, see P Pasquino 'Die Lehre vom "Pouvoir Constituant" bei Emmanuel Sieyès und Carl Schmitt' in H Quaritsch (ed) Complexio Oppositorum: Über Carl Schmitt (1988) 371; UK Preuss 'Carl Schmitt - Die Bändigung oder die Entfesselung des Politischen' in R Voigt Mythos Staat (2001) 141 .

35 Arato 'Post-Sovereign Constitution-Making in Hungary' (note 1 above).

36 Kelsen articulated the role of constitutional rights in modern democracies classically in terms of the need to protect minorities against democratic majorities (dieser Minoritätsschutz ist die wesentliche Funktion der sogenannten Grund- und Freiheits-oder Menschen und Bürgerrechte, die in allen modernen Verfasungen parlementarischer Demokratien garantiert sind). The standard quality of this insight and its familiarity should not blind one to its profound epistemological and definitional implications. Constitutional rights not only and not simply protect minorities, they also sustain and guarantee the very analytical essence of the majority principle itself on which democracy turns. The majority principle itself anticipates and announces the expectation of a split vote; it gets or got accepted as a principle exactly because no unanimity is and can be expected, exactly because it anticipates the continued existence of a minority. It remains a majority only to the extent that it honours, respects and maintains the minority by conceptual virtue of which it is constituted as a majority and not just as some or other overpowering force (die [Majorität ist] schon begrifflich ohne Minorität nicht möglich). Hence Kelsen's contention that it is better to refer to the majority principle as the majority-minority principle (man bezeichnet es darum besser als das MajoritätsMinoritätsprinzip). And then follows Kelsen's crucial move: The moment a majority would legitimate its views with reference to truth or ultimate wisdom, it would dismiss the significance of the minority view or wisdom and would by that dismissal destroy also its own claim to being a 
The essential difference between these two traditions of constitution-making and constitutionalism, the Schmittian and the Kelsenian, turns on an essential tension between two fundamentally different but deeply or inextricably entwined economies that inform constitution-making, namely the economy of the gift and the economy of sacrifice. Sovereign constitution-making prioritises the economy of sacrifice. Post-sovereign constitution-making prioritises the economy of the gift. Section IV looks more closely into this difference between gift and sacrificial economies.

\section{The Economy of the Gift and the Economy of Sacrifice}

Ulrich Preuss makes the following observation with regard to constitutionmaking processes:

Constitutions come into being after a revolution or war, but in either case the people are deeply involved. After a revolution - the most intense kind of internal social conflict - the triumphant forces lay out their principles of how society should be ordered. This is tantamount to imposing their rule upon the defeated groups who are then usually denounced as 'counter-revolutionary,' 'reactionary,' or sometimes even as 'enemies of the people.' Constitution-making after a war is not very different. If the war was lost, then the demoralized masses place the blame for their defeat and sufferings on the now 'old regime', which has proved itself unable to defend the essential interests of the nation. They throw their rulers out of office and the desire for a new beginning manifests with the demand for a new constitution expected to reflect their needs, hopes and aspirations. But even after a victorious war, a new distribution of power, i.e. a new constitution, is on the agenda of the nation. The people want recognition and remuneration for their sacrifices and hence demand a new distribution of the benefits of the social compact. ${ }^{37}$

Preuss' use of the word 'sacrifice' in the last lines of this passage may well be more incidental than intentional. We regularly use the word 'sacrifice' in an every day language to simply denote some dear price paid in pursuit of some or other goal, the paying of which subsequently entitles the payer to significant recognition, compensation, or entitlement. This is surely the first and most obvious layer of meaning that is conveyed in this passage. Closer scrutiny nevertheless also reveals elements in the passage that go to the heart of the deeper economies of sacrifice to which theorists like Henri Hubert and Marcel Mauss, on the one hand, and René Girard, on the other, have alerted contemporary social science and philosophy. In this regard Preuss' resort to

majority. The moment it would resort to truth claims to sustain its legitimacy, it would forfeit its 'mere majority' status and betray its democratic legitimacy for the sake of some other - most likely political-theological if not down right theocratic - legitimacy. Such then is the irreducible errancy to which democracy admits. Democratic debate is not, as democratic ideology sometimes suggests, about finding the truth. It has no significant access to truth (even if it would have access to truth that access would not be democratically significant). Democratically significant is only the ability to sustain compromises, that is, the ability to sustain majority-minority relations (wenn das spezifisch dialektisch-kontradiktorische Verfahren des Parlaments einen tieferen Sinn hat, so kann es nur der sein, dass aus der Genüberstellung von Thesis und Antithesis der politischen Interessen [nicht etwa ... eine 'höhere', absolute Wahrheit, ein über den Gruppeninteressen stehender, absoluter Wert, sondern ein Kompromiss] zustande komme). For the passages and phrases cited here, see Kelsen Vom Wesen und Wert der Demokratie (1981) 53, 57, 58.

37 UK Preuss 'Perspectives on Post-Conflict Constitutionalism' (2006/7) 51 New York Law School LR 469, emphasis added. 
the world 'sacrifice' in this passage, however incidental it may have been, serendipitously highlights the deeper sacrificial economies at play in constitutional change and constitution-making. These economies include, beyond the mere contractual quid pro quo that first comes into view, the ritual practices required to give new beginnings adequate existential purchase, on the one hand, and the ritual identification of scapegoats, on the other.

Primitive religions, argue Hubert and Mauss, understood the origins of all things in terms of a first sacrifice. Not only the earthly worlds of mortals, but also the celestial expanses of the gods themselves emanated from ritualised sacrificial practices. ${ }^{38}$ A common understanding of religion may have it that the gods require humans to sacrifice, but Hubert and Mauss teach us that it is really the other way round: Humans have gods because they sacrifice. To this insight Girard adds another: Ritual sacrifices in primitive cultures concerned the need to interrupt and terminate miasmic escalations of violence in communal life. Aware of the way an eruption of violence invariably precipitates a logic of revenge, repeating circles of which lead to disastrous escalations of violence, primitive communities sought to interrupt and terminate this logic of revenge with an arbitrary or a-logical identification of a scapegoat that could be blamed and sacrificed. Rationalised legal systems, argues Girard, would eventually displace the arbitrary identification of scapegoats with reasoned constructions of the guilty criminal, but as a substitute for primal sacrificial sacrifices, these rationalised legal systems still bear a close link to the logic of sacrifice that informed earlier ritual practices. ${ }^{39}$ That criminal accusation is indeed a form of community founding is well recognised also by contemporary sociologists. ${ }^{40}$

Both these ritual elements are evident in Preuss' description of constitutionmaking processes in the wake of revolution and war. On the one hand there is the need to lay down, with sufficient gravitas and dramatisation, a new social order and new social foundations. On the other hand there is the need to blame and accuse, that is, the need to identify enemies and counter-revolutionaries. And the violence and bloodshed and cruelty that accompany the latter clearly nourish the gravitas and dramatisation required for the proper staging of the former. That these sacrificial energies go to the heart of sovereignty and thus also mark the constitution-making that Preuss is describing here as the sovereign mode of constitution-making of which Arato's post-sovereign constitution-making seeks to take leave, has been registered well in political theory and philosophy. Already in the $18^{\text {th }}$ century Joseph de Maistre identified sacrificial criminalisation as the essential connection between God and earthly rulers that endows the latter with the former's sovereignty. ${ }^{41}$ The link between sacrifice and sov-

38 H Hubert \& M Mauss Essai sur la Nature et La Fonction du Sacrifice in M Mauss Oeuvres 1. Les Fonctions Sociales du Sacré (1968) 297-9.

39 R Girard La Violence et Le Sacré (1972).

40 See for instance G Pavlich 'Accusation: Landscapes of Exclusion' in W Taylor (ed) The Geography of Law: Landscape, Identity and Regulation (2006) 65; 'The Lore of Criminal Accusation' Criminal Law and Philosophy (2007) 79; 'Forget Crime: Governance, Accusation and Criminology' (2000) 33 The Australian and New Zealand J of Criminology 136.

41 See J De Maistre Eclaircissement sur Les Sacrifices in Oeuvres Complètes, Tome 5me (1924) 283-59. I am indebted to Martin Loughlin for this reference. 
ereignty has also been articulated poignantly more recently by the Strasbourg philosopher Jean-Luc Nancy. ${ }^{42}$

In view of this clearly perceived link between sacrifice and sovereignty in political theory and philosophy, it seems compelling to argue that Arato's round table model of post-sovereign constitution-making also envisages a post-sacrificial understanding of constitution-making. It envisages a founding of new communities that would not turn on scapegoating and accusation and would not depend on the rituals of bloodshed and cruelty to adorn itself with adequate gravitas. On what would these new foundations and new forms of communal founding turn and depend instead? The most likely candidate for this replacement would be the need simply to forgive. New founding would turn on the gift of forgiving. In this regard the crucial insight for Arato's model could again come from Arendt: Nothing new can come into the world, she argued, without the gift of forgiving. ${ }^{43}$ Arato's round table of constitutional negotiators knuckles down to a task mindedness aimed at making a new beginning. Accusation and criminalisation, both backward-looking in essence, can only frustrate the attempt to start again. ${ }^{44}$

42 See J-L Nancy Le Sens du monde (1993) 141: 'À ce compte, la politique doit être destin, avoir l'histoire pour carrière, la souveraineté pour emblème et le sacrifice pour accèss. Il faudrait retracer l'histoire impressionante du sacrifice politique, de la politique sacrificielle - ou de la politique en verité, c'est-à-dire du "théologico-politique": depuis le sacrifice expressément religieux jusqu'aux diverses Terreurs, et à tous les sacrifice nationaux, militants, partisans, Politique de la Cause à laquelle le sacrifice est dû. En cela, tout le théologico-politique, jusque dans sa 'sécularisation', est et ne peut être que sacrificiel'.

43 Arendt The Human Condition (note 15 above) 236-43. See also Ricoeur La mémoire, l'histoire, l'oubli (2000) 630-37 for an incisive discussion of this point in Arendt.

44 Just how radically Arato approaches this matter is apparent from his insistence that moralising programmes like 'de-Nazification', ‘de-Communization' or 'de-Baathification' already risk a sovereign imposition on the constitution-making process that is not reconcilable with the 'postsovereign model'. See Arato 'Post-Sovereign Constitution-Making and its Pathology in Iraq' (note 1 above) 548: 'It was essential to the new method of constitution-making that pluralistic, consensual legitimacy replace democratic legitimacy in the first stage of the process. This is why the round tables tried very hard to include all the major contending forces of society in the bargaining process. Their logic was incompatible with revolutionary purges, including de-Nazification and de-Communization processes'. This logic, argues Arato, was unfortunately not followed in Iraq where a 'de-Baathification' was also applied to the bargaining process and resulted in the general disorganisation of state structures. With this radical inclusivity Arato can be said to move even beyond Arendt into a certain Derridean territory. Arendt still maintained a distinction between the forgivable and the unforgivable and excluded the latter from the new political beginnings that might issue from the forgiving. See Arendt The Human Condition (note 15 above) 241. Derrida maintained to the contrary that only the forgiving of the unforgivable in his, her or its unforgivable status warrants conceptually sound invocations of the word 'forgiveness'. The insistence that only the forgivable or the sufficiently repentant can be forgiven turns the gift of forgiving into a reciprocal transaction in which nothing is really forgiven. See J Derrida Cosmopolitanism and Forgiveness (2002) 27-60, especially 32-9. Seen from this perspective, Arato's model turns on an almost miraculous hospitality or generosity. One might not want to invoke this lofty and demanding language here and perhaps just wish to let the matter go with the pragmatic inclusiveness and cool and frank public spiritedness with which Frank Michelman describes constitutional civility. See in this regard the text accompanying footnote 48 below. But it is a good question whether this cool and frank civility (Michelman's inimitable trademark in my books) can ultimately be severed from or contemplated consistently without some consideration of the miraculous magnanimity or hospitality that seems to be required here. 
The following picture of Arato's model is taking form here: Instead of Schmitt's unitary understanding of the political, it endorses Arendt's understanding of politics in terms of plurality. Instead of the Schmittian/De Maistrian concern with the political as essentially a matter of sacrificial scapegoating (the friend/enemy distinction in Schmitt, criminalisation in De Maistre), it endorses an economy of forgiving and giving. Instead of De Maistre's vertical political-theological chain (the great chain of being) ${ }^{45}$ that runs from God to the sovereign and the essential link of which is constituted by criminalisable subjects, it endorses an almost incomprehensible equal footing between former enemies or former oppressors and the victims of their oppression, notwithstanding the moral high grounds the latter may correctly and justifiably wish to claim. In other words, instead of the verticality of sovereignty, it endorses what Nancy might call a 'horizontality of mortals', l'horisontalité des morts. ${ }^{46}$ Arato's post-sovereign constitution-making concerns a horizontal constitution-making and ultimately, a horizontal constitutionalism.

Why this horizontal constitutionalism cannot be imagined to be anything but a more or less Rawlsian liberal constitutionalism also follows from the logic of the gift. At issue in post-sovereign constitution-making is not only the future-oriented willingness to forgive past wrongs and injustices, but also the willingness to give up, at least as far as future constitutional or foundational values are concerned, all present aspirations and truth claims that stand no chance of common endorsement by all the parties involved in the constitution-making process; hence the inevitable narrowing or stripping down of comprehensive worldviews to minimal principles of public reason that liberal constitutions evince. Post-sovereign constitution-making in multi-cultural, multi-religious, and multi-political societies not only requires forgiving histories of past suffering and injustices that may be existentially precious ingredients of present identities. It also requires giving up, at least to some extent, these and many other precious historical elements of present identities for the sake of common futures. ${ }^{47}$ It goes without saying that the

45 For insightful descriptions of this symbolism of verticality, see JW Daly 'Cosmic Harmony and Political Thinking in Early Stuart England' (1979) Transactions of the American Philosophical Society 1-41; W Ullman The Individual and Society in the Middle Ages (1967); W Ullman Medieval Political Thought (1975); G Duby The Three Orders. Feudal Society Imagined (1982). The position of the king as absolute sovereign and therefore as completely at the top of the earthly hierarchy only materialised towards the end of the middle ages and especially during the reformation with the maturation of the idea of the divine right of kings. This idea was a result of the king eventually winning the long battle between state and church for ultimate authority on earth. For the classic discussion of this development see JN Figgis The Divine Right of Kings (1934) especially 17-65. I am indebted to Chris McCorkindale for the reference to Daly.

46 J-L Nancy Corpus (1992) 49. See also J Derrida Le Toucher, Jean-Luc Nancy (2000) 253-4.

47 See Rawls (note 33 above) 243, discussing the duty of civility that requires resignation regarding the 'imperfection' and even 'shallowness' of public reason in comparison to the "whole truths" of comprehensive worldviews. That one should understand the apparent 'shallowness' of public reason that Rawls points out here as in fact an inverse or negative depth is an argument that I am currently pursuing in new research on Arendt and the law that will be published in a volume of essays on Hannah Arendt and the Law edited by Chris McCorkindale and Marco Goldini and published by Hart Legal Publishers in 2011. 
duty of civility that thus also comes to rest on the shoulders of the forgiven becomes immense and unfathomable.

It is worthwhile to note the interesting link between Arendt and Rawls that emerges here. Against backgrounds of constitution-making that require forgiving the past and embracing present complexities and pluralities, something that is almost invariably the case in contemporary political transitions anywhere in the world, both Arendt and Rawls disqualify the idea of constitutions that can be entirely ours or entirely our own. That there is indeed an Arendtian regard for the need to forgive embodied in Rawls' notion of public reason and public civility that requires everyone to give up on their comprehensive conceptions of truth, the notion of a public reason or public civility that requires everyone to give up visions of truth that are entirely their own for the sake of less expansive truths that everyone involved in the common existence of a polity can share, becomes especially clear in the poignant line Frank Michelman adds to this Rawlsian position: Constitutionalism, argues Michelman, turns fundamentally on a method of avoidance. It turns on the civil ability to live with differences by avoiding them as far as possible when they are clearly intractable. This civility surely includes the ability to engage with and articulate our (citizens and residents of constitutional democracies) differences. This is what the plurality of the political is all about. But ultimately it is also about getting over these differences when there is no reasonable chance of resolving them through finding consensus. As Michelman puts it: '[Constitutionalism] hopes to vault people past their real, unliquidated disagreements and uncertainties regarding the actual, substantial merits - the all things considered rightness, goodness, or prudence of ... laws and other legal acts ... It invites the parties to such disagreements and uncertainties to slide past them, "get over" them ...,48

'Sliding past' and 'getting over' differences for the sake of continuing co-existence under the rules of a constitutional democracy may turn to a considerable extent on considerations of prudence and rational choice, and Rawls ultimately tends to cast his defence of public reason in such terms. ${ }^{49}$ But there is no way that we can rid the demands of civility and public reason of risk, of the risk that the civility one offers will not be honoured and reciprocated by others. There is always the need for someone to take the first step towards civility, to make the first gesture of civility, without the luxury of a guarantee that this step and gesture will be accepted and respected. To be sure, reciprocity seems to be the more current or available the more first gestures of giving turns into a veritable economy of giving; the more the first gift is consolidated by counter-giving and a veritable system of potlatch, as Mauss and Derrida might have put it; the more an initial modus vivendi turns into significant overlapping consensus, as Rawls might have. This is why, in the wake of a considerable history of constitutional democracy it does eventually become tempting and plausible to speak of 'constitutional guarantees'. But 
realist political and legal theorists never escape from the awareness of the real historical frailty and fragility of all human arrangements and all things human. For them, the distinction between a precarious modus vivendi and a more secure overlapping consensus remains exposed to its own historicity and to the historical instability that always accompanies this historicity. For them, constitutional democracy is not the end of history, but one of the (perhaps more fruitful) historical attempts to deal with history. For them, constitutional democracy and the peace and security it offers can therefore never be exclusively a matter of rational choice. The guarantees it offers are ultimately always too frail and precarious to warrant such a conclusion. In the final analysis it always turns on an element of sheer giving and hospitality. Constitutional democracy ultimately turns, in the final analysis, on a politics of liberal and indeed free (gratis) friendship. There is no away around this insight.

The insight into the element of giving and hospitality on which constitutional democracy turns requires scrutiny into the nature of the gift that is at issue here. Against the actual backgrounds of constitution-making and constitutionalism in contemporary Africa and the contemporary world, Africa's gift to the world and to itself would not consist in the kind of gift that Biko envisaged as Africa's gift to the world. It would consist exactly in giving up that kind of gift (gifts of 'ultimate' or 'superior' substantive wisdom) ${ }^{50}$ and giving up that understanding of giving (giving as giving down or handing down), at least as far as the founding of new African polities and the writing of new constitutions for these polities are concerned. As far as the gift of post-sovereign constitution-making is concerned, giving consists in giving up as much as is necessary to make future peaceful existence possible. However, an important caveat or qualification is crucially important here. At issue here is surely not a naive politics of selflessness. At issue here is ultimately nothing but a common-sense understanding of what it means to negotiate and compromise in good faith: giving up as much as is necessary, no less but surely also no more, than is necessary to make the future possible. However, it is exactly with regard to this 'no less' and 'no more' that we need to take a brief look at the South African constitutional transition. In this regard one would have to engage with at least three critical areas of concern:

(1) Endorsing the liberal values of constitutional democracy surely requires giving up aspects of traditional African ways of life, as the judgment of the Constitutional Court in Bhe and Others v Magistrate Khayelitsha has

50 One can imagine Frank Michelman wanting to ask in this regard: What makes you so sure your liberal constitutional 'giving' is entirely a matter of 'giving up' substance and entirely devoid of 'offering', 'giving down' and indeed imposing substantive wisdoms? See F Michelman 'Constitutionalism as Proceduralism: A Glance at the Terrain' in E Christodoulidis \& S Tierney (eds) Public Law and Politics. The Scope and Limits of Constitutionalism (2008) 141. The response would of course be that one can never be sure about this, but the aspiration of a certain critical liberalism, of which Michelman himself is probably one of the most dedicated and acute exponents, is indeed to give up instead of giving down substantive wisdoms that may interfere with peaceful co-existence. 
shown. ${ }^{51}$ But it also requires a constitutional commitment to safeguard and honour as much of these traditional ways of life as is reconcilable with the liberal values of constitutional democracy. I cannot engage with this concern adequately here but wish to point out the significant initiative that Michelman has recently taken in this regard. ${ }^{52}$

(2) Suspicion and cynicism are afoot, especially among the political left, that South Africa's 'miraculously peaceful' transition was orchestrated by and between the capitalist business elite of the apartheid era and the leadership of the ANC. This is a serious matter with which I do wish to deal, if only provisionally and surely still inadequately so, in section $\mathrm{V}$ of this article. It is important to deal with this matter here, because it surely raises the question whether some South Africans have not given up much too much for the sake of a 'common' future, the 'commonness' of which may well be puzzling them by this time.

(3) Forceful recent scholarship on the proceedings of the TRC poses the question whether the suspension of the regular rule of law in favour of exceptional amnesty procedures did not impose on some South Africans a heavier burden than was reasonable and necessary for purposes of making the transition to constitutional democracy possible. I deal with this briefly in section VI of this article.

\section{Subterranean Capitalism and the Surreptitious Return of SACRIFICE}

Let us return to the maxim coined above regarding the irreducible element of giving and the gift that makes constitutional democracy possible. At issue in this gift that gives us constitutional democracy, I averred, is not a naive politics of selflessness, but a common-sense understanding of what it means to negotiate and compromise in good faith: giving up as much as is necessary, no less but surely also no more, than is necessary to make the future possible.

There is of course no way that one can establish correct measures of necessary giving exactly or precisely. One traverses a grey area here where the absence of a clear line between necessary and excessive giving effectively blurs the line between giving and sacrifice. Who gives too much, sacrifices or makes a sacrifice; who gives too little, demands a sacrifice in sovereign fashion; ${ }^{53}$ hence the astute observation of the mad protagonist Alexander in

51 Bhe v Magistrate Khayelitsha; Shibi v Sithole; SA Human Rights Commission v President of the RSA 2005 (1) SA 563 (CC); 2005 (1) BCLR 1 (CC).

52 Michelman (note 29 above).

53 Derridean purists would complain that I am invoking a contractual reciprocity of giving here that is entirely at odds with the lack of reciprocity in any giving that is worthy of the word. My reading of the matter is this: Neither Mauss nor Derrida assumed the possibility of pure giving. Giving is always tied into potlatch economies of gifts and counter-gifts. However, there is a pure margin of giving that does not relate to the object of giving but to the fact of giving, the fact that someone takes the risk of giving without knowing for sure that the counter-gift will be forthcoming and without means of enforcing the counter-gift. The potlatch does not allow for such enforcement. Were it to do 
Tarkovsky's film The Sacrifice that '[e]very gift requires its own sacrifice'. ${ }^{54}$ This is probably the most pervasive experience among humans regarding the relation between giving and sacrifice, given the lack of a clear boundary between the end of giving and the beginning of sacrifice. This does not, however, prevent us from discerning evident imbalances of giving. And evident imbalances of giving may well be one of the crucial threats to the future of constitutional democracy in South Africa today, one that threatens the legacy and promise of South Africa's horizontal constitutional transition fundamentally. And the evident imbalance of giving most pressingly at issue in South Africa today, no longer concerns the relationship between the ANC and NP leaderships around the negotiation tables. At issue here are much rather the negotiations between ANC leadership and the apartheid business elite that predate the political negotiations in Kempton Park. And the nagging question that haunts South Africa today concerns the way these negotiations between the ANC and the apartheid business elite shoved a burden of excessive giving, the burden of sacrifice, again onto the weary shoulders of the masses of black people impoverished by decades of colonial and racist politics in South Africa. $^{55}$

The ANC had its first public meeting with the South African business elite in 1990. The message of business to the ANC was expressed clearly by Gavin Relly, at that time chair of Anglo American, South Africa's largest corporate conglomerate.

$[\mathrm{W}] \mathrm{e}$ in the corporate sector believe that the retention of domestic and international investor confidence is critical to economic growth ... if investors conclude that state intervention and regulation stifle initiative, entrepreneurial activity and the ability to make profit, capital and skills flight will ensue. Renewed foreign capital inflows - in contrast to the capital outflow that is now taking place on a significant scale - are vital to the kind of economic growth that will allow SA to successfully tackle her development agenda. ${ }^{56}$

The ANC's response to this message was clearly accommodating, provided the need to redress the 'grossly unequal distribution of economic power' and

so, there would be no difference between economies of the gift and contractual economies. Giving thus always assumes the risk of giving without receiving the counter gift. And in doing so it gives time and does so absolutely. It gives the time in which the counter-gift may be forthcoming or not. Thus does it actually give the whole potlatch and the community that depends on it or derives from it, a chance. See in general J Derrida Donner le temps 1. La fausse monnaie (1991); M Mauss Essai sur le Don in Sociologie et anthropologie (1950).

54 A Tarkovsky The Sacrifice (1968). I am indebted here to insights gained from a viewing and discussion of this film in the working group on The Sacrificial Contours of Law, Liturgy and Landscape in the Law School and Theology Department of the University of Glasgow, funded by the Leverhulme Trust in terms of their Artist in Residence Scheme.

55 Refer in this regard especially to RW Johnson 'False Start in South Africa' (2009) 58 New Left Review; P Bond 'In Power in Pretoria?' (2009) 58 New Left Review. I am indebted to Emilios Christodoulidis for bringing these publications to my attention.

56 G Relly 'Options for Building an Economic Future' (1990) 33 Investment Analysts Journal, partly re-quoted here from S Gelb 'Inequality in South Africa: Nature, Causes and Responses' (2004) African Development and Poverty Reduction: The Macro-Micro Linkage, Forum Paper $30<\mathrm{http}: / /$ www.sarpn.org.za/documents/d0000671/index.php>. I am indebted to Peter John Massyn for this reference to Gelb's paper and for insightful conversations about the issues addressed in the paper. 
'deracialisation' of economic power would become part and parcel of the overall deal with business. In the words of Mandela:

We accept that both the [national and international business] sectors are very important to the process of further development or our economy. We can therefore have no desire to go out of our way to bash them and to undermine or weaken confidence in the safety of their property and the assurance of a fair return on their investments. But we believe that they too must be sensitive to the fact that any democratic government will have to respond to the justified popular concern about grossly unequal distribution of economic power. ${ }^{57}$

Stephen Gelb responds to this 'accommodation' between the ANC and business as follows:

[The broad outline of the dominant policy framework had been clear at the start of the transition. Structural factors meant that the model would rest on the accommodation between the ANC and big business, creating a distributional coalition of white business and emerging black business, resting on policies to promote globalisation and BEE [Black Economic Empowerment]. While the form of BEE was still unclear, it soon began to be spelled out. ${ }^{58}$

'Agency focussed' suggestions that the ANC simply 'sold out', argues Gelb, do not take into account the real structural exigencies of the South African economy with which the new political elite had to deal. Such suggestions 'overemphasise lack of political will and skill and ignore structural features of society ... which beset the economy' and are therefore indeed 'simplistic' and 'moralistic' as Gelb points out. ${ }^{59}$ And yet, the way BEE shamelessly turned into an empowerment programme from which only a small number of well-connected individuals would benefit spectacularly, does raise serious questions as to how long the ANC elite remained seriously concerned with broad-based black empowerment. And if it were so that this lack of concern with broad-based empowerment - and 'lack' would denote here any margin of compromise with and further entrenchment of the existing economic status quo that was not dictated strictly by structural exigencies of the economy was significantly present during the constitutional negotiations, it would make a mockery of the transformative concern to 'heal the divisions of the past' and 'improve the quality of life of all citizens' explicitly voiced in the preamble of the 1996 Constitution.

Why so? Well, because of the way emerging BEE practices lock and have locked the South African economy into a low growth path that renders progressive and sustainable change unlikely, if not impossible. BEE, having been reduced to spectacular package deals for a much too small and more or less exclusive number of 'rent-collecting' politically well-connected 'patrons' who are not real business entrepreneurs in any known sense of the word, severs 'black economic empowerment' from growth and undermines the latter fundamentally. As Gelb explains, a sustainable and progressive programme of change would have had to turn on the close links between empowerment 
programmes and growth that Keynesian models of economic change emphasise. Keynesian connections or 'feedback links' between redistribution and growth must turn on broad-based and general improvement of income levels. It cannot result from the advancement of a select few, a select few, moreover, whose contribution to the economy does not consist in adding substantive value (entrepreneurial skills that actually contribute to profit-making and growth) but solely in legitimising patronage. ${ }^{60}$ Such patronage, being essentially a rent-collecting institution, does not add but diminishes (creams off) real value. Talk about rectifying past injustices must take on a new and rather surprising meaning against this background. To put it starkly: the sincerity of those who negotiated for the progressive realisation of the socio-economic rights contained in ss 26, 27 and 29 of the 1996 Constitution surely begins to appear questionable against this background. And such questionability may ultimately come to cast considerable shadows over the incredible compliment Arato has paid South Africa by imputing to it the perfection of post-sovereign constitution-making. It may well still turn out to have been a perfect counterfeit of the model. For it ominously looks like millions of South Africans are again being asked to give too much while a select few reap excessive sovereign benefits. It ominously looks as if the age-old link between sovereignty and sacrifice of which Nancy reminds us, is again showing its face in South Africa today.

It is, however, of utmost importance to stress Gelb's observation regarding the simplistic and moralistic nature of any suggestion that the ANC leadership simply 'sold out' when they made the deal with the apartheid business elite. Facile and moralistic suggestions of this kind must end with the cynical conclusion that the South African transition to 'constitutional democracy' was nothing but a matter of self-interested power play and manipulation. Far from a matter of vertical sovereignty giving way to horizontal constitutionalism, the transition was a matter of sovereignty returning in the form of subterranean capitalism, the cynics and the moralists would hold. Cynicism and moralism have a long record of going hand in hand, but this record rarely reflects incisive critical scholarship. However, proper critical scholarship does demand a response to this cynicism and moralism should it wish to offer a persuasive alternative view and vision. The response that I wish to offer in this regard is this:

Historical developments never have intrinsic meanings that can be abstracted from the histories to which they belong, subsequent or future histories included. Neither the deal between the ANC and the apartheid business elite nor the negotiations in Kempton Park had intrinsic meanings that somehow determined and still explain the historical developments in their wake. We are long past the days of psychological or intentionalist hermeneutics in social scientific and historical research and even longer past using the findings of such hermeneutics as causal explanations for later events. Social scientists 
worth their salt know today that the meaning of historical events invariably turn on the meaning they acquire in the course of subsequent histories and as a result of those histories. The meaning of history turns on the irreducible retroactivities that the future imposes on it. History is always made much later than naive causal explanations of the present might think. South Africans too, are today still constantly making and re-making the past from which they come. They can choose today whether they remake the deal between the ANC leadership and the apartheid business elite and turn it into a betrayal, a sellout if you wish, of the people they claimed to liberate, or whether they wish to maintain and sustain that deal as matter of historical wisdom and prudent statecraft, as it may well have been intended in good faith at the time. And in making this choice regarding the deal between the ANC and the apartheid business elite, they will inevitably also make a choice as to whether they will turn the political negotiations in Kempton Park into a noble event of horizontal constitution-making and horizontal constitutionalism, or an orchestrated farce to which Andrew Arato has paid a noble but undeserved compliment.

As things stand, South Africans appear to be caught in two competing retroactivities. On the one hand, there is high level corruption that takes the form of bizarre BEE practices, patronage and rent-collecting that would seem to go out of its way to make a mockery of the ideals of constitutionalism and good government that many if not most South Africans associated with the constitution-making process in Kempton Park. On the other, there are those who cannot and will never believe that the long years of incredible sacrifice (indeed of giving more than any human can be expected to give or any human can expect to receive) that went into the liberation struggle were nothing but a facade for cynical self-advancement. The latter South Africans still believe in the reality of constitutional democracy in South Africa. They clearly do so against significant odds. They carry the fire Cormac McCarthy style.

\section{TRUTH AND RECONCILIATION}

It should be clear from the above that I read Arato's model of constitutionmaking as an inspiring endeavour to move away from a sacrificial approach to constitution-making. I read the model as an endeavour to premise the foundation of polities on an economy of the gift and forgiving and not on the contractual reciprocity ('we offer cooperation in exchange for ...') that demands significant new sacrifices for past sacrifices. A new political dispensation can only be truly inclusive and truly an endorsement of plurality when it pivots, to some extent, on an initial gift. Only thus shall we ever be able to understand constitutional democracy in terms of a friendship that is not owed, deserved or paid for in any way, but gratuitously given and received, as only friendship can be given and received. Only thus can we begin to think of law and constitutionalism as not, or not exclusively, a matter of sacrifice. But it remains a question whether a completely non-sacrificial politics and non-sacrificial law can be contemplated realistically among mortals. And in asking this question we need not at all entertain thoughts regarding the necessity for 
revolutionary or post-revolutionary purges of the kind Preuss articulates in the passage quoted above. We need not contemplate exceptional sacrifices required by states of exception. But we need to ask whether and to what extent any transitional or polity-founding state of exception warrants, on the other hand, the suspension of the regular sacrificial elements of regular law. ${ }^{61}$

At issue here is a call to reflect on the role of amnesty proceedings that suspend the regular rule of criminal and civil law during political transitions. It is obvious that such amnesty proceedings can unburden and facilitate these transitions in the short run. One may well ask whether the miraculous South African transition would have been possible without them. But the question whether such amnesty proceedings do not come back to haunt and to eventually undermine 'successful' political transitions in the long run must also be asked. One is possibly or potentially facing another destructive retroactivity here. Elements of the populist and traditionalist dissatisfaction with the Constitution current in South Africa today may well relate to a sentiment that the Constitution did not really found a new state or polity. This sentiment probably responds mostly to the tardy tempo of socio-economic transformation which more than one and a half decades down the line has left too many people in the state of disempowerment that the racist apartheid economy imposed on them. But it may well also relate partly to pervasive dismay among South Africans regarding the way the amnesty proceedings conducted by the TRC deprived them of an understandable desire for ordinary criminal and civil justice. ${ }^{62}$

This is the way the transition panned out in South Africa and it is doubtful whether much can be done about it at this late stage and whether it ever could have panned out otherwise. But future reflections on Arato's post-sovereign model of constitution-making may well benefit from engaging purposefully with these questions, as may future transitional processes. Perhaps the lesson from South Africa is simply this: If one is going to ask victims of criminal and delictual acts perpetrated by the oppressors of old to forego rightful criminal charges and rightful civil law claims for the sake of facilitating a political truce and transition, one had better be willing and able to empower them significantly in other respects, especially socio-economically. If one cannot achieve the latter, the former is bound to precipitate or contribute to discontent

61 The inevitable sacrificial elements of ordinary law have been a constant theme in my writings in recent years. See especially Van der Walt (note 12). Consider in this regard one example that I have articulated more recently. Proof of criminal intent in criminal trials rely fundamentally on presumptions on the basis of which mens rea is constructed without the trial being able to effect a direct equation between evidence and the state of mind of the accused. This construction of mens rea effects a sacrificial relation, an irreducible element of scapegoating to put in Girardian terms, between the law and the law enforcing community, on the one hand, and the accused, on the other, no matter how strong the forensic evidence is and irrespective if the accused was caught 'red handed'. For a more extensive discussion of this point, see Van der Walt (note 22 above) 718-25.

62 Richard Wilson argues forcefully that the 'politics of reconciliation' was a strategy with which the $\mathrm{ANC}$ leadership sold their forfeiture of sovereignty to their constituencies. The ANC elite began to preach the virtue of forgiveness, he contends, to silence the demands of justice that they failed to honour during the negotiations. See RA Wilson The Politics of Truth and Reconciliation in South Africa (2001) 5-18. 
with the new constitutional and legal order. Such discontent can manifest itself in many ways. Signs of constitution-unfriendly populism and traditionalism evident in South Africa today may well have been spawned by the combined effect of tardy socio-economic transformation and the suspension of regular criminal and delictual justice during the years of transition. The economy of the gift, giving and forgiving that I discern in Arato's post-sovereign model of constitution-making can easily be overburdened and it may well have been overburdened in South Africa.

When one asks a formerly oppressed people to give up so much on all fronts, one is surreptitiously slipping out of a gift economy and back into an economy of sacrifice. For one is then effectively prolonging the erstwhile economy of sovereign sacrificial oppression, or launching it anew. When one does this, one may well be kindling new sacrificial yearnings that exceed by far the critical minimum of sacrificial satisfaction that the regular rule of law can and should offer. ${ }^{63}$ When one does this, one surely invites the eruption of disastrous retroactivities.

\section{CONCLUding OBSERVATION}

Commenting on Derrida's point regarding the retroactive legitimation of the past, Arato writes:

While in forthright claims of revolutionary legitimacy a future can retroactively legitimate the past, a bashful revolutionary legitimation that dresses itself in the colors of modern competitive party politics, but hides various levels of elite bargaining, cannot be sufficient to ground a new constitution. ${ }^{64}$

Arato is not talking about South Africa here, but many South Africans may well want to read into this passage an eerily accurate assessment of what may have passed as South Africa's miraculous transition. If this reading were to carry any substance in future, as it would if more readers would come to entertain it, the South African Constitution may soon lack the grounding it needs to sustain a stable constitutional order. And if this were indeed to become the case, we would be in a particular spot of bother. For Arato contends, correctly I think, that not even a Derridean deconstructive regard for the retroactivity that attaches to and ultimately makes or breaks all grounds of legitimacy is going to help us out here. Well, if this really were to become

63 One is of course breaking out of a strict Girardian understanding of sacrifice when one articulates the matter this way. Girard argues that sacrificial rituals were aimed at halting escalating circles of violence. See Girard (note 39 above). The point made above suggests that sacrificial rituals can themselves spawn circles of sacrifice. The accuracy of this suggestion would turn on whether the distinction between sacrificial violence (purified and purifying violence) and non-ritual violence (polluted and polluting violence) is stable or not. I cannot go into this here, but my suggestion is clearly that it is not.

64 Arato 'Constitution and Continuity in the East European Transitions I' (note 1 above) 106; Civil Society, Constitution, and Legitimacy 182. Arato refers here to Derrida's arguments in 'Force of Law: The Mystical Foundation of Authority' in D Cornell et al (eds) Deconstruction and the Possibility of Justice' (1992) 35, but also see J Derrida 'Declarations of Independence' (1986) New Political Science 7. 
the case, we would need a stronger retroactivity here, a profoundly faithful constructivist retroactivity that can create something out of thin air. This may have been the gist of Frank Michelman's contention, during the Glasgow Workshop on Constitution-Making in 2009, that a stained or imperfect history of constitution-making is not all that bothersome when the outcome of this history is a product to which one can be faithful and remain faithful. Whether this faith can hold against all historical and empirical odds is the critical question with which this article contends. But perhaps it is in the nature of real or stronger faith not even to ask this question in advance.

Where have you gone, Professor Kelsen? A nation turns its lonely eyes to you. ${ }^{65}$ 